Article

\title{
Collaborative Environmental Governance, Inter-Agency Cooperation and Local Water Sustainability in China
}

\author{
Chen Huang ${ }^{1}$, Tao Chen ${ }^{1, *}$, Hongtao $\mathrm{Yi}^{2, *}$, Xiaolin $\mathrm{Xu}^{1}{ }^{1}$, Shiying Chen ${ }^{1}$ and Wenna Chen ${ }^{3}$ \\ 1 College of Public Administration, Huazhong University of Science and Technology, 1037 Luoyu Road, \\ Hongshan District, Wuhan 430074, China; helen_huangchen@163.com (C.H.); xiaolin@hust.edu.cn (X.X.); \\ chensy@hust.edu.cn (S.C.) \\ 2 John Glenn College of Public Affairs, The Ohio State University, 1810 College Rd., \\ Columbus, $\mathrm{OH}$ 43210, USA \\ 3 Department of Public Policy, City University of Hong Kong, Tat Chee Avenue, Kowloon, Hong Kong, China; \\ wennachen2-c@my.cityu.edu.hk \\ * Correspondence: chentao15@163.com (T.C.); yi.201@osu.edu (H.Y.)
}

Received: 17 November 2017; Accepted: 9 December 2017; Published: 12 December 2017

\begin{abstract}
Administrative fragmentation among government agencies has posed a significant challenge to environmental governance. However, few studies have theoretically examined and empirically measured how local governments in China address this with collaborative approaches. Informed by the ecology of games framework (EGF), this paper examined the status of inter-agency water governance in Dongguan City: the pilot city of aquatic ecologically friendly city of China. The research question we seek to address is: What are the main characteristics of the water governance network in local China? With empirical data collected via survey questionnaires and semi-structured in-depth interviews following the EGF, we find that local agencies have realized the need for cooperation in water resource management. However, they were not substantially familiar with each other in the local policy network, failing to reach their full potential in collaboration. Social network analysis was used to analyze the collaborative network. We found that the network has a weak to moderate density, allowing for collective action problems and leading to insufficient cooperative governance. The network has presented central actors with strong bridging capital to control information and resource flows. We also find strong bonding capital among some policy actors as shown in high reciprocity, clustering coefficient and transitivity. To strengthen the effectiveness of local water governance, efforts should be made to establish a functional department and extend the boundary of collaborative network.
\end{abstract}

Keywords: water governance; network governance; inter-agency cooperation; environmental sustainability; ecology of games; collaborative governance

\section{Introduction}

Effective environmental governance requires vertical interactions among different administrative levels and horizontal interactions across different jurisdictions [1]. However, administrative fragmentation among horizontal departments has been a critical public administration problem [2-4]. The involvement of multiple departments often leads to inefficient cooperation, which has been a primary challenge for environmental governance [5]. Fragmentation has also led to various institutional collaborative solutions, including inter-jurisdiction agreement, intergovernmental networks and inter-local consolidation. In contrast to traditional bureaucratic structure, network governance presents an innovative approach to implementing public policy by building interdependent relationships among governments, businesses and civil society [6-8]. 
Water, a natural and economic resource, is critical for the survival of human beings. Along with the development of economy and the expansion of population, water resource is the most exiguous resource in the future, as it significantly constrains the supply of food, energy, and other goods and services [9-11]. Besides, water resource is often inevitably intertwined with other natural systems, such as land use and atmosphere systems [12]. All these issues fall under different jurisdictions of administrative departments in the context of China, and the critical challenge is how to enhance governance effectiveness through inter-agency collaboration $[13,14]$. Over the past few decades, scholars and policy makers contended that the enhancement of water governance is the key to solve water-related policy issues $[15,16]$.

The rapid economic development in China has imposed immense stress on its ecological systems, especially the water ecological system, as China is currently faced with serious water-related challenges, such as water shortage, water pollution, water eco-system degeneration, and water disasters. Although China has rich total volumes of water resources, its per capital volume is relatively low [17]. Water resources are also unevenly distributed across different regions, which has further intensified the conflict between the supply and demand of water. Meanwhile, due to its ineffective administrative system, water governance in China produced undesirable results. China has a three-tier administrative system of water resources, including the Ministry of Water Resources at the national level, watershed management institutions at the regional level, and departments of water resource management at the local level. Although governments at national level are quite ambitious and comprehensive in achieving water governance objectives and policies, governments at the local level have not been able to fully implement the centrally imposed environmental policies [18]. Water governance has historically suffered from administrative fragmentation in China, in which multiple agencies are tasked to manage similar policy areas.

Administrative fragmentation issues are rampant, as regional institutions and local governments share overlapping jurisdictions and authorities, causing an institutional collective action (ICA) dilemma in which the management of water resources is ineffective and inefficient [2]. An ICA dilemma often occurs in fragmented systems, where one functional governmental department can affect the decision making of other functional departments [19]. If all departments only pursue their short-term goals, this will lead to an ICA dilemma, which negatively affects integrating decisions across policies and/or jurisdictions [19]. Lubell argues that policy actors engaging in different policy venues are embedded in an ecology of games, which address some the collective action dilemmas through joint participation in policy forums [20]. However, no studies have empirically tested the ecology of games framework (EGF) in the context of China.

This paper fills this gap by answering the following research questions: what are the features of the inter-agency cooperation in local China? What are the key problems facing local water governance in China? Has administrative fragmentation led to the formation of inter-agency cooperation network in the local water governance? What are the main characteristics of the water governance network in local China? To answer these questions, this paper examines inter-agency cooperation in local water governance as informed by the EGF, with empirical data on the water governance network in Dongguan City, Guangdong Province. The data on the governance network were collected via questionnaires circulated among 21 municipal departments with water-related responsibilities, based on an adaptive application of the EGF survey [21]. Network data are also validated via in-depth interviews with department managers from Dongguan Water Affairs Bureau, Dongguan Environmental Protection Bureau and other water management departments. Applying network analysis and descriptive statistics, this paper examines the current status of water governance and existing water policy problems in Dongguan. This paper contributes to extant theoretical discussions on water governance in China in particular, and the literature on sustainability governance and policy networks in general.

The next section presents a review of extant literature on water governance and network governance, with discussions of their implications in China. We then present the situation of water governance in Dongguan City, our study site for this paper. We then show a detailed research design 
with questionnaires and in-depth interviews. Descriptive statistics and network analysis are conducted to analyze the problems and situation of network water governance in Dongguan. We draw theoretical and policy implications in the last section of the paper.

\section{Literature Review}

\subsection{Water Governance, Network Governance and Ecology of Games}

The concept of governance has been widely studied in water policy research [22]. According to Rogers and Hall, water governance refers to the management of water resources and provision of water resources through political, social, economic and administrative systems [23]. It is better implemented via a governance network, in which policy actors engage in cooperative relationships and a joint decision process [24]. Effective and integrative management of water resources is believed to be an important approach to achieving effective water governance [16]. Integrated water resource management (IWRM) requires all related influential factors and stakeholders to optimize economic and social welfare as well as the sustainability of ecosystems [25]. However, IWRM is hard to implement due to the lack of an institutional framework [12], which focuses on polycentric governance, bioregional scale, public participation and experimental approaches [26]. In addition, in recent years, scholars have started to concentrate on the nexus approach, which treated water affairs as a cross-cutting issue which need to be considered in the context of all other relevant governance procedures by all related sectors [12]. All three methods have realized the importance of the governance process, the limits of governmental power and the significance of diverse actors.

As the demand for water grows, water-related conflicts and problems are presenting urgent pressures to policy makers, requiring better "rules of the game" for water governance. Improving water governance is not just about simply changing particular rules, but is more importantly related to who participates and how to participate [27]. Although "participation gap" is a common governance issue [28], some empirical research has showed that local activity would neither increase the local decision-making power nor decrease the national power [29]. Multi-dimensional involvement, in terms of different levels, sectors and scales [30], could help resolve some of the conflicts [31]. The intervention from higher levels of government into the policy process requires collective actions, but stakeholders, such as local governments and interest groups, have difficulties in reconciling their interests [32,33]. Therefore, network governance is focused on establishing complex interaction processes in terms of solving the collective action dilemmas [34]. It links relevant stakeholders by forming formal or informal relationships embedded in vertical and/or horizontal cooperative networks [35-37].

In the local ecology of policy games, this involves governmental and non-governmental actors from different administrative levels [38]. Lubell and Lippert clarified roles and responsibilities of different stakeholders, and found governmental actors with public resources, information and administrative authorities, often occupy central roles in the governance network [39]. Hence, interactive activities among them would exert positive influence on network effectiveness [40]. Non-state entities' participation in regional water governance could enhance the accessibility of the whole process [41], and citizen participation could supplement governments' effort on dealing with complex environmental issues [42].

Under the EGF, different configurations of network relationships may distinctively influence the results of water governance. Berardo and Scholz explained that configurations of the relationship in policy networks can be used to measure the underlying coordination and cooperative problems in the fragmented policy arenas [3]. Social capital helps enhance trust, lubricate social and political relations [43] and facilitate sustained cooperation within the policy network [35]. The solution to coordination problems requires bridging network social capital (bridging capital) offered by central actors that extend ties beyond their close actors and to other groups with whom they had less or no connection [44]. The solution to cooperative problems, on the other side, demands bonding network social capital (bonding capital) through which actors build relationships that brings them closer and 
establish close-knit structures in the network [44]. Moreover, bridging relationships allow actors to locate and evaluate potential collaborative partners, while bonding relationships help clear the obstacles to negotiation and reduce the transaction cost involved in the collaborative efforts [3].

In summary, scholars presented characteristics of water governance from different perspectives and argued that fragmented authorities create collective action problems, for which collaborative governance is the solution. The EGF especially emphasized the importance and influence of network governance and that social capitals are driving the formation of policy networks. However, very few studies have analyzed the current situation and challenges of water network governance in the Chinese context. This study fills these gaps by measuring and mapping the local water policy networks, as informed by the EGF.

\subsection{Water Governance in China}

Rapid urbanization and industrialization have led to a serious water crisis in China. China is typically characterized as a centralized country, its national government controlled all water bodies and is responsible for formulating and executing water policies [45]. In local governance, administrative fragmentation leads to overlapping jurisdictions and administrative partitions [46]. Although administrative partitioning is generally believed to enhance decentralization of authority and intensify competition among departments, it negatively influences managerial effectiveness and governance performance.

China is currently faced with tremendous challenges in environmental governance, with administrative fragmentation being one of the most serious problems [5]. As the key actor in environmental governance, the bureaucracy, including central government and authorities at other levels, designed the environmental accountability mechanism to strengthen the environmental governance performance [47]. Under the top-down authoritative system, traditional localized and disorganized models reduced the governance efficiency [8]. Effective policy implementation also required involvement across different administrative levels in different steps of the policymaking processes [33].

China's political and jurisdiction management system is also relevant for the study of its water governance. The governance of water typically involves departments in different watersheds and at different administrative levels, while overlapping responsibilities and infrequent cooperation among departments reduce its effectiveness. A complex network structure is needed to resolve water governance problems in China. Establishing a formal water governance network will improve cooperation among stakeholders by ameliorating administrative fragmentation issues. Specifically, this network structure calls for the integration of traditional top-down vertical administrative system with the emerging horizontal network [48].

\section{Water Governance in Dongguan}

Dongguan is located in the mid-south of Guangdong province in China, which is a half-hour commute from Huizhou, Shenzhen and Hong Kong (Figure 1) [49]. It has developed rapidly over the last 30 years and has become the manufacturing hub of the world. In 2015, about $4.55 \%$ of China's export GDP was contributed by Dongguan. As Dongguan falls on the lower stream of Dongjiang River, it traditionally has rich water resources. Because of its geographic proximity and abundant water resources, Dongguan has constructed the Dong-Shen water supply project to provide fresh water to Hong Kong. Its supply capacity has reached 1.1 billion cubic meters annually, with a cumulative supply over 22.8 billion cubic meters in the past 50 years, accounting for $70 \%$ to $80 \%$ annual water consumption in Hong Kong. 


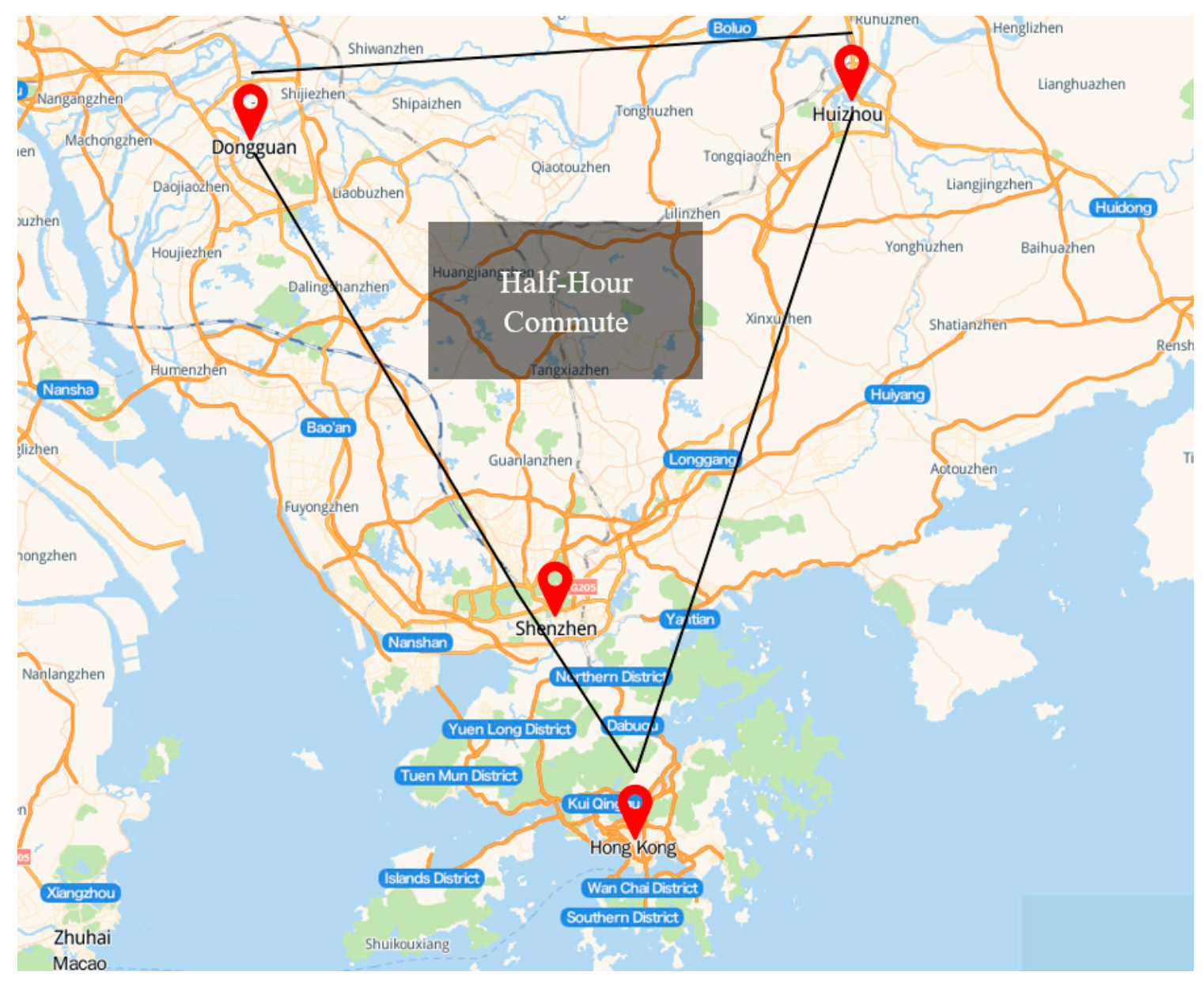

Figure 1. Geographical location of Dongguan City.

Along with fast development of manufacturing industries, Dongguan was faced with tremendous challenges in the governance of its water affairs, such as water resource shortage, water pollution, waste of water resource, and conflicts between water demand and water supply. Apparently, the traditional growth model is insufficient to satisfy current development requirements, heightening the contradictions between economic development and environmental protection. In recent years, as responses to the above water governance issues, Dongguan has spent more effort on enhancing water environment and water ecological restorations to construct an ecologically friendly city.

With the progress of implementing integrated management of water related affairs at the town level, inter-agency cooperation happens more frequently. A multi-level cooperative network emerged as the result of the reform. This paper examines the status and problems which have existed in the local water governance network in Dongguan, with the purpose of understanding the complexity of water governance in local China, as well as providing useful suggestions to local governments faced with similar situations in achieving effective local water governance.

\section{Research Methods}

In order to assess the status of the inter-agency cooperation of local water governance in China empirically, this article conducts in-depth interviews and surveys to collect network data in Dongguan. The research was conducted by a collaborative research team with members from universities in China and United States. The survey instrument was adapted from the survey questionnaire used in the Ecology of Games Framework [21], in which we asked the network relationships among policy actors, political activities that these actors participated and various questions that were used in previous 
EGF studies. The interviewees involve department managers from Dongguan Water Affairs Bureau, Dongguan Environmental Protection Bureau and other water-related administrative departments. Surveys were administered among 21 municipal departments, with help from Hydraulic Engineering Society of Dongguan. The whole research period lasted over one and half years from 2015 to 2016. SPSS 19 (IBM: New York, NY, USA, 2010) and UCINET 6.632 (Analytic Technologies: Lexington, KY, USA, 2016) were employed to analyze the network data. Due to the exploratory nature of the study, provincial departments and regional departments, public and other non-state participants were not included in the network boundary.

\subsection{Interviews}

In order to understand the operation of government agencies responsible for water governance, we designed customized interview guideline questions and interviewed ten departmental managers. According to the Pilot City Implementation Scheme of an Aquatic Ecologically Friendly City, complied by the Water Affairs Bureau (WAB), five key objectives were established during the pilot period (from Year 2014 to Year 2016). During the three years, Dongguan has decided to establish five key systems, including a water management system, water assurance system, water security system, water environmental system and water cultural system [50]. In this scheme, it listed 21 key participants and described their responsibilities in detail. As it takes much time and effort to interview all these departments, we picked ten representative offices and departments as the interviewees, to whom we posed questions related to their responsibilities (as shown in Table 1). Interview outlines were given to them in advance to make sure interviewees were well prepared for the interview.

As WAB is the leading department in water governance, we interviewed different offices of WAB, including the Water Ecological Office, Policy and Regulation Office, Water Resource Management Office, Water Pollution Control Office, Communications Office and General Affairs Office. During the interview, we focused on the cooperative activities among these offices, and their inter-organizational relationships with other municipal departments and town departments. At the same time, we interviewed departmental heads from Dongguan Water Investment Organization and Environmental Protection Bureau, regarding their responsibilities in water governance and the extent of cooperation with other departments. Besides this, we picked two town governments with different watershed locations and varying water governance performance-Houjie and Machong-as our interview targets at the town level. Houjie is located in the upstream of Dongjiang River, which shows better performance in water governance, while Machong is located in the downstream of Dongjiang River, with relatively inferior water governance. In the interview process, interviewees helped us identified the boundary of the local water governance network, which we used as our sampling frame in the survey implementation.

Table 1. List of interviewees and overview.

\begin{tabular}{|c|c|c|}
\hline ID & Department Name & Interview Overview \\
\hline 1 & $\begin{array}{l}\text { Dongguan Water Investment } \\
\text { Organization }\end{array}$ & $\begin{array}{l}\text { Water governance takes a long period of time to establish: it is a good idea } \\
\text { to set up obligatory targets for responsible departments. Jinan city, as the } \\
\text { first Aquatic Ecologically Friendly City of China, is a good example for } \\
\text { other cities. Meanwhile, effective water governance cannot work } \\
\text { successfully without clear division of responsibility. }\end{array}$ \\
\hline 2 & $\begin{array}{l}\text { Water Ecological Office } \\
\text { of WAB }\end{array}$ & $\begin{array}{l}\text { WAB established an information sharing platform, where departments at } \\
\text { town level can report to WAB in a timely way and communicate with each } \\
\text { other effectively. In terms of promoting water governance, it is necessary to } \\
\text { enhance the cooperative activities with Huizhou, Shenzhen and other } \\
\text { neighboring cities. Besides this, Dongguan did not have a department to } \\
\text { assess water governance performance, and it did not set up a quantitative } \\
\text { assessment index yet. }\end{array}$ \\
\hline
\end{tabular}


Table 1. Cont.

\begin{tabular}{|c|c|c|}
\hline ID & Department Name & Interview Overview \\
\hline 3 & $\begin{array}{l}\text { Policy and Regulation Office } \\
\text { of WAB }\end{array}$ & $\begin{array}{l}\text { In recent years, Chinese legislature has set up a series of regulations and } \\
\text { documents on environmental protection. But there is no specific law or } \\
\text { regulation on water protection. It is really important to intensify law } \\
\text { enforcement efforts on water governance. }\end{array}$ \\
\hline 4 & $\begin{array}{l}\text { Water Resource Management } \\
\text { Office of WAB }\end{array}$ & $\begin{array}{l}\text { After the reform of administrative system in water affairs, administrative } \\
\text { approval, enforcement and other administrative power have been } \\
\text { decentralized. Departments at town level were empowered to do } \\
\text { administrative activities. However, departments were not well familiar } \\
\text { with each other, which then limits the overall performance of water } \\
\text { governance. }\end{array}$ \\
\hline 5 & $\begin{array}{l}\text { Water Pollution Control } \\
\text { Office of WAB }\end{array}$ & $\begin{array}{l}\text { Different offices were in charge of different stages of water pollution } \\
\text { governance, which could easily lead to administrative fragmentation. It is } \\
\text { necessary to enhance cooperation and collaboration among these offices. }\end{array}$ \\
\hline 6 & Water Ecology office of WAB & $\begin{array}{l}\text { To enhance the awareness among stakeholders about the importance of } \\
\text { water ecology and encourage public participation, Dongguan tracks and } \\
\text { reports the process of the construction of water ecology friendly city on } \\
\text { government official website, Weibo, Wechat and other official platforms. }\end{array}$ \\
\hline 7 & $\begin{array}{l}\text { General Affairs Office } \\
\text { of WAB }\end{array}$ & $\begin{array}{l}\text { Dongguan encouraged public participation: they published water } \\
\text { governance related information on newspapers, broadcast, Wechat and } \\
\text { other platforms. They also built a good relationship with Environmental } \\
\text { Protection Bureau and organized education activities together. }\end{array}$ \\
\hline 8 & $\begin{array}{l}\text { Environmental Protection } \\
\text { Bureau }\end{array}$ & $\begin{array}{l}\text { One of the most serious problems of water governance in Dongguan is the } \\
\text { shortage of latest technology. Regarding the water governance at town } \\
\text { level, Hangzhou city and Qingdao City are good examples. In terms of } \\
\text { water governance, EPB of those cities were responsible for compensating } \\
\text { pollution. However, control from the source is very important to } \\
\text { sustainable development. }\end{array}$ \\
\hline 9 & $\begin{array}{l}\text { Agriculture and Forestry } \\
\text { Bureau of Machong Town }\end{array}$ & $\begin{array}{l}\text { Integrated water resource management cannot be achieved, because towns } \\
\text { downstream of the Dongiiang river have to pay for the pollution generated } \\
\text { upstream. Machong seldom collaborated with other towns. As different } \\
\text { towns are focused on their own interests with different administrative } \\
\text { methods, it is hard to achieve effective cooperation on water governance. }\end{array}$ \\
\hline 10 & $\begin{array}{l}\text { Agriculture and Forestry } \\
\text { Bureau of Houjie Town }\end{array}$ & $\begin{array}{l}\text { One of the main sources of water pollution is industrial waste. Due to the } \\
\text { limit of staff, this problem has not been well resolved yet. Hence, it is } \\
\text { necessary to spend more effort on managing at the root of pollution and } \\
\text { encouraging public participation. }\end{array}$ \\
\hline
\end{tabular}

\subsection{Surveys}

Based on the EGF, proposed by Lubell, Scholz and Berardo [21], we designed a questionnaire to investigate the inter-agency cooperation of water governance in Dongguan, with 11 questions covering the objectives, procedures and effectiveness of local water governance. Briefly, this questionnaire includes five aspects, including the evaluation of overall performance of water governance in Dongguan, key responsibilities, coordination circumstance, obstacles of cooperation, and main cooperative partners. All the questions are multiple choice questions, but respondents are allowed to provide their own opinions if they could not find eligible options. According to Pilot City Implementation Scheme of Dongguan City, we identified 21 municipal departments as key actors in water governance of Dongguan and their responsibilities. This document helps us identify a broad range of governmental agencies who involved in water governance in the construction of ecological civilization, not just those responsible for water management traditionally. We had mentioned the survey questionnaire to participants and explained the purpose of the questionnaire to them during the initial contact. This questionnaire was also covered with an introductory letter to explain the purpose of research. At the same time, it was administered on behalf of the Dongguan Hydraulic Engineering Society to ensure a high response rate. The questionnaire was distributed via email, Wechat (a social networking app) and regular mail. 
In terms of ensuring the response rate, we reminded them twice a week through either telephone calls or Wechat messages, and we offered the opportunity to answer the questionnaire via telephone as well. After several rounds of efforts, we received 21 responses for a response rate of $100 \%$.

\subsection{Social Network Analysis}

Social network consists of a set of actors and connective relationship between them [51], and social network analysis (SNA) is a methodology to analyze and visualize these connection patterns [52]. SNA, which is also called structural analysis [53], is a strategy for investigating social network structure in terms of nodes and ties [54]. Different to traditional individualistic social theory, the top priority for SNA is to identify relationship between actors [54]. Besides this, it focuses on analyzing the relationships between structural regularities and an actor's behavior [54].

This study examines how different departments (referred as nodes in social network) acted in the local water governance network, and how the relationships among them (referred as ties in social network) influence the overall performance of local water governance. Therefore, in order to build a network matrix, we chose the Likert Scale to acquire connections data in terms of how one department connected to other departments. We used SPSS to calculate mean values and standard deviations of the general understanding of local water governance. Using the SNA method, we built a cooperative network, and then analyzed its density, centrality, reciprocity, clustering, and transitivity measures. The following sections will demonstrate our analysis in detail.

\section{Analysis and Discussion}

\subsection{Moderate Familiarity among City Departments}

Effective inter-agency communication is required to enhance the efficiency and effectiveness of cooperation. In order to understand the extent of familiarity among municipal departments in Dongguan, a question asking "For water issues most important to you, would you say that you know the policy interests of the most active water management governmental agencies in Dongguan, in terms of their responsibilities and their roles in water governance?" was designed using the Likert scale to measure the degree of familiarity among departments. The respondents recorded responses in scales ranging from 1 (completely unfamiliar) to 7 (fully familiar).

Calculated by SPSS, the average score of inter-agency familiarity is 4.38 with a standard deviation of 1.86, which demonstrates that most of the departments were moderately familiar with each other's responsibilities and tasks. Such familiarity among different departments also varies across agencies: for instance, the Science and Technology Bureau (STB, 4.8\%) demonstrated no familiarity with other departments, who were peripheral in the governance of water affairs and stood at the edge of cooperative network. Municipal Government (MG), Financial Bureau (FB) and Oceanic \& Fishery Administration (OFA) answered that they are completely familiar with other departments, indicating that a few agencies are playing leadership roles in organizing the policy network. These agencies are potentially acting as the central coordinators, similar to what Berardo and Scholz identified in their study of Tampa Bay policy network [3].

Our empirical study focuses on cooperative water governance in local China, where ambiguous responsibility allocation and ineffective policy communication among governmental agencies leads to collective action problems. One interviewee from the Environmental Protection Bureau (EPB) mentioned that "the administrative structure is too flat, which intensifies the problems further and thereby leads to unsatisfactory performance in water governance". To resolve these problems and improve the effectiveness of water governance in Dongguan, it is necessary to clearly define responsibilities for all involved departments and communicate the divisions of responsibilities among them. Granovetter found that networks with a more extensive "weak tie" have better performance than those with a smaller and denser "strong tie" for job seekers [55]. Departments located in the 
center of the governance network should play leading roles in involving and informing departments who are less familiar with other agencies, especially ones located at the edge of the network.

\subsection{Partial Cooperation among Departments}

Given that municipal agencies are collaborating with each other to form the inter-agency network, it is important to understand how agencies evaluate the level of cooperation among them. In the questionnaire, we used a question to measure the intensity of cooperation, asking "Overall, how would you describe cooperation between municipal departments of Dongguan?". The answers were coded "1" to "7" following the Likert scale, corresponding to "no cooperation at all" and to "full cooperation".

Based on the response to the survey, the mean score of cooperation was 4.33, indicating most departments only achieved partial cooperation among departments. A standard deviation of 1.59 indicated minor differences across departments in their opinions. This can be compared with Mark Lubell's research in California [39], which found that the perceived cooperation rate among IWRM participants is 4.8 on average: a number slightly higher than Dongguan. From the comparison results, we can conclude that both of the two cities were at a moderate level of cooperation in water governance, with room for enhancement in the future.

While most agencies reported partial collaborations with others, there were $4.8 \%$ departments not satisfied with the status of cooperation, including Housing \& Urban-Rural Development (HURD) and STB, as they reported that they were not familiar with other relevant departments and had few connections with other participants. At the other end of the spectrum, OFA noted full cooperation has been achieved among agencies in water governance, as it is completely familiar with other water-related departments regarding water affairs, which therefore showed a better collaborative relationship. Such variation indicated that the cooperative network needs to be further consolidated in breadth and depth so that policy actors' subjective evaluations can be improved.

The above analysis was conducted to understand the status facing the local water governance, based on data gathered from questionnaire. According to the answers, departments in Dongguan only demonstrated moderate familiarity with each other, while inter-agency evaluation of cooperation is intermediate. Departments demonstrated higher familiarity with other departments showed higher satisfaction with cooperative water governance in Dongguan. Combined with results and information collected from the interview, we found that most agencies report little control over their roles, insufficient support from departments from higher level government, and strong departmental protectionism. The following section will report results from the perspective of social network analysis.

\subsection{Network Governance}

During the process of constructing aquatic ecologically civilization city, local government agencies in Dongguan have made a strong commitment to effective water governance, which calls for the emergence of collaborative networks among diverse agencies [56]. From the perspective of local governance, building mutual interrelationship between different departments is a significant step toward collaborative governance [56]. On the principle of integrated administrative system, Dongguan finished the reform of water affairs integration at the municipal level. After transition, WAB was in charge of the comprehensive management of water governance in Dongguan, which covers the previous responsibilities of the Water Conservancy Bureau, Urban and Rural Water Supply, and Water Pollution Governance, acting as the key actor in the cooperative network [57]. Even though WAB has already integrated the above water-related government functions, it needs collaborative support from other departments in terms of policy, finance, and information from EPB, Development and Reform Bureau (DRB), Planning Bureau (PB), the Bureau of Land and Resources (BLR) and FB. The WAB-led water governance is then expanded to a cooperative network, which we will now describe and analyze with network analysis.

We use UCINET, a software for social network analysis [51], to analyze the network structure of the policy network. Graphical visualization was conducted with Netdraw, a component of UCINET. 
In the inter-agency relational data gathered from questionnaire, we assigned a value of " 1 " to a reported tie between two agencies, and " 0 " otherwise. We constructed the water governance cooperative network in Dongguan. It has 21 participants, covering all water-related departments in the Dongguan municipality. Figure 2 shows the water governance cooperative network, with nodes representing actors and ties representing relations between them.

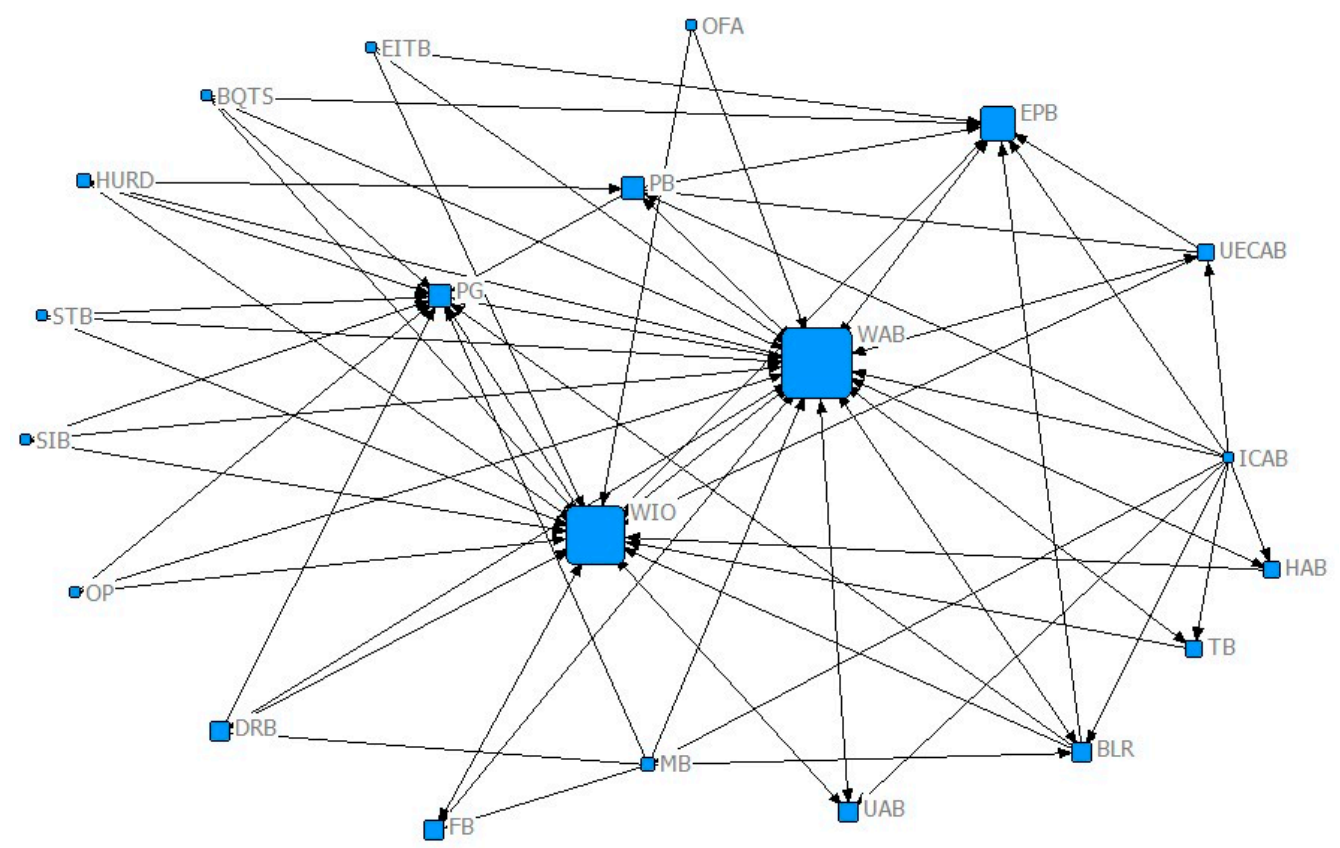

Figure 2. Visualization of water governance network. PG: the People's Government; OP: Propaganda Department; WAB: Water Affairs Bureau; EPB: Environmental Protection Bureau; DRB: Development and Reform Bureau; FB: Financial Bureau; UECAB: Urban Engineering Construction Administration Bureau; UAB: Urban Administration Bureau; BLR: Bureau of Land and Resources; BQTS: Bureau of Quality and Technology Supervision; TB: Transportation Bureau; PB: Planning Bureau; EITB: Economy \& Information Technology Bureau; HURD: Housing and Urban-Rural Development Bureau; ICAB: Industrial and Commercial Administration Bureau; SIB: Statistical Burea; STB: Science and Technology Bureau; OFA: Ocean \& Fishery Bureau; MB: Meteorological Bureau; HAB: Highway Administration Bureau; WIO: Water Investment Organization.

\subsection{Network Density}

Network density, an indicator for network integration and cohesion [58], measures the number of ties within the network compared to the numbers of total possible ties. Calculated with UCINET, in the Dongguan Case, the number of ties within the network is 77, while the total connections of this network are 420 . Therefore, the density score for the water governance network of 0.1833 is obtained by dividing 77 over 420 , which means that $18.33 \%$ of all possible ties between actors are present. As network density is highly dependent on the size of network, the Dongguan water governance network demonstrates a weak to moderate density based on its network size. The smaller the density score, the fewer the numbers of bilateral connections, the less the shared resource and information, and the less extensive the inter-agency cooperation [59]. This confirms the results reported previously, that a large portion of departments agree that they only achieve moderate cooperation in the water governance. Interviewees at town level mentioned that "current policies did not fully consider the actual circumstance of different towns and thus lead to unsatisfactory performance, which was mainly affected by insufficient cooperation". Without sufficient cooperation, it is hard to create mutual confidence and facilitate information exchange and resource sharing within the network [60,61]. However, according to empirical research, Ulibarri and Scott found the interesting 
conclusion that a network with lower density but fewer propensities and stronger interactions present higher cooperation [62]. This indicates that cooperative action and frequent interaction among actors, especially key actors, are the key factors driving highly effective cooperation. At the same time, a network with high density is needed in that dense, overlapping networks of reciprocity offer credibility and social capital, which are critical to the solution of collective action problems $[63,64]$.

\subsection{Bridging Capital: Power, Influence and Brokers}

Bridging capital gives actors power and influence. To be more specific, actors who have bridging connections are able to control information and resource flows in the cooperative network, enjoying comparative advantages over other actors in the network $[35,65,66]$. Network centralization is a measure of how a network is centered on key actors [67], illustrating the distribution of power and authority within the network [68]. Calculated with UCINET, the degree centralization of the cooperative network is $77.37 \%$, with an in-degree of $80.5 \%$ and out-degree of $43.74 \%$. The nearer the degree centralization approximates to 1 , the closer the network is to highest centralization. The results above indicated that the water governance network demonstrates high centralization, which means a small number of actors attracted the majority of connections within the network, indicating the presence of central coordinators as shown in Tampa Bay water governance networks in the United States $[3,69]$. The great difference between in-degree and out-degree indicated that large portions of connections within the network were generated by actors proactively sending links, and only a small number of actors passively received links from others.

Another measure of bridging capital is the degree centrality measure, which counts the number of connections each actor establishes. Actors with higher degree centralities stand in dominant positions to influence others and the overall performance of the network [70], as they are capable of enhancing communication flow within the network [69]. In Dongguan Water Governance network, WAB, PG, $\mathrm{EPB}, \mathrm{WIO}$, and ICAB had highest degree centralities, playing the roles of central coordinators. These five departments are the key actors located in the center of the water governance network, with the highest political authority. For example, the degree centrality of WAB is 20, which means it has connected with 20 other departments and stands in all the connection paths of the network. This reflects that WAB possessed strong network power to the rest of the actors in the network, through controlling information exchange and resource sharing [71]. High degree centrality suggests that WAB has strong connectedness and is capable of transmitting communication within the entire network. The empirical evidence reflects the design principles from the local government to set up a water governance system, in which WAB plays leading roles and the rest of the departments playing supporting roles.

The 'betweenness' centrality captures actors' capabilities to control communication and information flow within the network. From the overall perspective, the 'betweenness' centralization of the cooperative network is $38.7 \%$ based on the calculated results with UCINET. With relatively high 'betweenness' centralization, information flow within the network largely relies on a few actors. Meanwhile, with a high modularization, nodes in different organizations may be separated with low trust among them, reducing the chance to construct the cooperative network. From the individual point of view, the 'betweenness' centrality of WAB and WIO, who are the central actors of the network, are much higher than other departments. Central actors require fewer links to reach other actors, as they controlled the majority of resources and had a large effect on the connections to other nodes. However, by comparing in-degrees and out-degrees, we find that they did not play central roles effectively as the bridge, which is different from the findings of Scholz et al. that estuary political actors with high 'betweenness' centrality and degree centrality prefer joint activities [35]. As central actors exert control over more connections as well as resources and information, they are in unique positions to promote more collaborative activities, boost information sharing within the network and create more connections to expand the boundary of current network.

The establishment of bridging capital dominant structures is usually determined by central actors [44], which are often called brokers. They fulfilled coordinating roles by developing connections 
with sub-groups and avoiding overlapping actions. They act as bridges that create indirect connected ties for nodes [72], representing important influence on network structure. According to the cooperative network (as shown in Figure 2), WAB builds connections with all departments, while PG only creates one tie with WAB. If PG wants to connect to other departments, it fully relies on WAB, who acts as the broker in this connection. As a broker, WAB controls the information flows on latest policy trends and resources available. This also helped WAB to utilize its leading and coordinating role in reinforcing coordination with other departments and strengthening the inter-agency cooperation of water governance in Dongguan. Besides this, one of the officers from WAB said in the interview that "we formed a group to maintain relationships, and this group had a positive effect on solving conflicts within the collaborative network".

\subsection{Bonding Capital: Reciprocity, Clustering and Transitivity}

The benefit of bonding capital is that dense and overlapping relationships create trust, which increases the probability of sustaining cooperation over time. Reciprocity is one of the basic configurations of bonding capital, which engenders trust and sends positive signals to other actors about building strong relationship with them [3]. A highly reciprocal network is dominated by symmetric connections. In the water governance network of Dongguan, the hybrid reciprocity is 0.22 , which tells us that this cooperative network is dominated by a hierarchical structure, that some "popular" actors create non-symmetric relationships. For example, WIO is one of the central actors of the cooperative network: its symmetric score (0.235) is much lower than its non-symmetric score (0.765), which decreases the benefits of bonding capital and makes it hard to reach cooperation.

Clustering coefficient is one of the conventional measures for bonding capital. It calculates the numbers of links between an actor's partners that exist over the total number that could exist, and offers an overall indication of clustering in the network [73]. Higher values in clustering coefficient indicate more overlapping linkages within the network, representing higher levels of trust, belief consensus and capability in solving collective action problems. As expected, the overall clustering coefficient of the water governance cooperative network is 0.53 , while its weighted cluster coefficient is 0.231 . Berardo claimed that the higher the clustering in the network, the larger the amount of bonding capital [44].

Transitivity is another representation of bonding relationship, which calculates the proportion of all possible triads in the network, thereby informing the proportion of expected fully transitive triads that are actually fully connected [51]. Putnam argued that redundant and overlapping ties in the network decrease transaction costs of resolving collective action issues, thus increasing the probabilities of cooperation between actors [74]. The transitive triad is shown to be a good indicator of trust, as has emerged from repeated interactions of closed groups [75]. In the cooperative network, transitive triads account for about $1.6 \%$ of total number of triples, and $10.46 \%$ of number of triangles with at least two legs. This means that some actors in this water governance network are connected to others with dense and redundant relationships, creating bonding ties to solve cooperative problems.

The analysis demonstrated collaborative activities within the water governance network of Dongguan (all the statistical results were as shown in Table 2). Generally, departments took the initiative to build a relationship with others and tried to expand their cooperative network, but the comparatively low density demonstrated that more bilateral connections are required for effectively sharing resources and information. Meanwhile, after the reform of water affairs integration, WAB took the leading position of water governance in Dongguan, and nurtured and accumulated sufficient bridging capital in governing water resources. However, the discrepancy between in-degrees and out-degrees 'betweenness' centrality showed that WAB were passive collaborators in joint activities. Furthermore, dense and redundant connections generated bonding capital that helps the policy actors solve cooperation problems. 
Table 2. Results of social network analysis measures.

\begin{tabular}{lc}
\hline Measures & Results \\
\hline Density & 0.1833 \\
Degree centralization & $77.37 \%$ \\
Betweenness centralization & $38.7 \%$ \\
Hybrid reciprocity & 0.22 \\
Overall clustering coefficient & 0.53 \\
Transitive triads & $1.6 \%$ \\
\hline
\end{tabular}

\section{Conclusions}

A fragmented system could lead to collective action dilemma, which could have horizontal, vertical and functional manifestations [4]. From the EGF perspective, this paper examined the status of inter-agency water cooperation in Dongguan City, China, in terms of solving network collaboration problems. As an institutional innovation, network governance has been experimented with in Dongguan, whose experiences and lessons are potentially relevant for other policy and national contexts. With empirical data collected via survey questionnaires and in-depth interviews informed by the EGF, we find that Dongguan has responded well to water governance issues, realized the significance of cooperative governance, and achieved integrated management of its water resources. Although the policy-making in Chinese local governments remains bureaucratic, network governance was introduced into the system to some extent, consistent with the findings on inter-agency collaboration in previous studies [76-78]. We found in this study that water-related governmental agencies in Dongguan were not substantially familiar with each other, thus they did not achieve full cooperation and reach the potential of cooperative water governance. By analyzing the cooperative network, we found this network has weak to moderate density, allowing for collective action problems. The network has also presented central actors with high power and control over information and resources. It also captures strong bonding capital among some policy actors, as shown in high reciprocity, clustering coefficient and transitivity.

Several policy implications can be drawn from this study. First of all, it is crucial to enhance the integration of local departments and strengthen the local cooperative network in Dongguan. As shown in this study, many departments responded that they were not familiar with each other and had low intentions to cooperate, due to infrequent communication plus ambiguous and overlapping responsibilities. This indicates the need to better communicate the responsibilities and functions of different departments. In this paper, we believed that trust building in terms of fostering bonding capital can serve as an alternative approach to promoting inter-agency cooperation, which will cultivate inner incentives for enhancing inter-agency cooperation.

Second, we found that the establishment of a functional department in charge of water affairs, $\mathrm{WAB}$, is helpful for addressing the fragmentation of water governance. A fragmented network that contains multiple network sub-groups disconnected with each other hinders information from flowing beyond the boundaries of each connected component, which thereby negatively influences the overall capacity of the network. The fragmentation issue can be solved by central actors through creating connections with disjointed parts of the networks. By setting up a special department such as WAB in Dongguan, this can serve as a central coordinator by sorting out responsibilities for different departments, facilitating information flows among other functional agencies and thereby avoiding ICA dilemma. The results illustrated that WAB did not reach the expected goals, which presented partial evidence in support of its effectiveness in governing water issues at the local level. The adoption of WAB is still a policy innovation in local governments in China, which required further improvement. By 2015 , there was no more than $50 \%$ of local governments that had adopted the WAB, and this paper shows that more local governments should follow the example of Dongguan in establishing a functionally integrated WAB in their jurisdictions to help facilitate network governance at the local level. 
Finally, it is necessary to extend the boundary of the cooperative network and involve more stakeholders in the environmental governance network. In local environmental governance, local government needs to place more emphasis on establishing vertical inter-agency cooperation with central government, provincial government, municipal departments and other departments at higher level. On the other hand, it is necessary to construct a platform that encourages information sharing, and equal participation from non-governmental policy actors, as are demonstrated in other national contexts in Vietnam [79], Pakistan [80] and Indonesia [81].

In terms of future research, this study presents a first step in developing and testing EGF in the Chinese context. Future studies can be conducted to examine the water governance in other local areas in China to allow for cross-case comparisons. Research should also be directed at understanding the behavior and motivations of a wider set of policy actors within the network, and at extending the network boundary to include enterprises, research agencies, NGOs and citizens, with the goal of understanding when and why policy actors participate in which policy venues. These studies would greatly enhance our abilities in evaluating the portability of policy theories in explaining policy phenomena across national contexts.

Acknowledgments: This work was supported by the Fundamental Research Funds for the Central Universities [grant number HUST: 2015QT008], the National Social Science Foundation of China [grant number: 14ZDA011], National Natural Science Foundation of China [grant number: 71373093] and the OIA Faculty Enrichment Grant "Water Governance in China: Fragmentation and Integration" at The Ohio State University.

Author Contributions: Xiaolin $\mathrm{Xu}$ and Tao Chen are jointly responsible for project development and research design. Shiying Chen and Wenna Chen are responsible for conceiving and developing introduction and research background. Chen Huang and Hongtao Yi are responsible for conceiving and developing literature review, research methods, analysis and discussion, and conclusions.

Conflicts of Interest: The authors declare no conflict of interest. The funding sponsors had no role in the design of the study; in the collect, analyses, or interpretation of data; in the writing of the manuscript, and in the decision to publish the results.

\section{References}

1. Cash, D.W.; Adger, W.; Berkes, F.; Garden, P.; Lebel, L.; Olsson, P.; Pritchard, L.; Young, O. Scale and cross-scale dynamics: Governance and information in a multilevel world. Ecol. Soc. 2006, 11, 8. [CrossRef]

2. Feiock, R.C.; Scholz, J.T. Self-Organizing Federalism: Collaborative Mechanisms to Mitigate Institutional Collective Action; Cambridge University Press: New York, NY, USA, 2010.

3. Berardo, R.; Scholz, J.T. Self-Organizing Policy Networks: Risk, Partner Selection, and Cooperation in Estuaries. Am. J. Political Sci. 2010, 54, 632-649. [CrossRef]

4. Feiock, R.C. The Institutional Collective Action Framework. Policy Stud. J. 2013, 41, 397-425. [CrossRef]

5. Dai, L. Recovering the costs of water services in the People's Republic of China: Lessons from Article 9 of the European Union Water Framework Directive. Utrecht Law Rev. 2012, 8, 102-118. [CrossRef]

6. Gaudreau, M.; Cao, H. Political constraints on adaptive governance: Environmental NGO networks in Nanjing, China. J. Environ. Dev. 2015, 24, 418-444. [CrossRef]

7. Ioppolo, G.; Cucurachi, S.; Salomone, R.; Saija, G.; Shi, L. Sustainable local development and environmental governance: A strategic planning experience. Sustainability 2016, 8, 180. [CrossRef]

8. Wu, Z; Tang, J.; Wang, D. Low carbon urban transitioning in Shenzhen: A multi-level environmental governance perspective. Sustainability 2016, 8, 720. [CrossRef]

9. Godfray, H.C.; Beddington, J.R.; Crute, I.R.; Haddad, L.; Lawrence, D.; Muir, J.F.; Robinson, S.; Thomas, S.M.; Toulmin, C. Food security: The challenge of feeding 9 billion people. Science 2010, 327, 812-818. [CrossRef] [PubMed]

10. Mulder, K.; Hagens, N.; Fisher, B. Burning water: A comparative analysis of the energy return on water invested. Ambio 2010, 39, 30-39. [CrossRef] [PubMed]

11. Wiek, A.; Larson, K.L. Water, people, and sustainability-A systems framework for analyzing and assessing water governance regimes. Water Resour. Manag. 2012, 26, 3153-3171. [CrossRef]

12. Gupta, J.; Akhmouch, A.; Cosgrove, W.; Hurwitz, Z.; Maestu, J.; Unver, O. Policymakers' reflections on water governance issues. Ecol. Soc. 2013, 18, 35. [CrossRef] 
13. Casiano Flores, C.; Vikolainen, V.; Bressers, H. Water governance decentralization and river basin management reforms in hierarchical systems: Do they work for water treatment policy in Mexico's Tlaxcala Atoyac sub-basin? Water 2016, 8, 210. [CrossRef]

14. Casiano Flores, C.; Boer de, C. Symbolic implementation: Governance assessment of the water treatment plant policy in the Puebla's Alto Atoyac sub-basin. Int. J. Water Gov. 2015, 3, 1-24. [CrossRef]

15. Saleth, R.M.; Dinar, A. The Institutional Economics of Water: A Cross-Country Analysis of Institutions and Performance; Edward Elgar Publishing Limited: Cheltenham, UK, 2004.

16. Biswas, A.K.; Torajada, C. Future water governance: Problems and perspective. Int. J. Water Resour. Manag. 2010, 26, 129-139. [CrossRef]

17. Guan, D.; Hubacek, K. Assessment of regional trade and virtual water flows in China. Ecol. Econ. 2007, 61, 159-170. [CrossRef]

18. Kostka, G. Barriers to the Implementation of Environmental Policies at the Local Level in China. Polity Research Working Paper. 2014, pp. 1-51. Available online: https:/ /ssrn.com/abstract=2487614 (accessed on 20 June 2017).

19. Feiock, R.C. Institutional Collective Action and Local Government Collaboration. Big Ideas in Collaborative Public Management. 2008. Available online: http://xueshu.baidu.com/s?wd= paperuri\%3A\%28c1f7df40d47ba35ced71f101a591f337\%29\&filter=sc_long_sign\&tn=SE_xueshusource_ 2kduw22v\&sc_vurl=http\%3A\%2F\%2Fciteseerx.ist.psu.edu \%2Fviewdoc\%2Fdownload\%3Bjsessionid \% 3D9938B931F88CB7773A7269D26F15ED57\%3Fdoi\%3D10.1.1.457.9478\%26rep\%3Drep1\%26type\%3Dpdf\& ie $=u t f-8 \& s c \_u s=10778209009000654071$ (accessed on 12 October 2016).

20. Lubell, M. Governing Institutional Complexity: The Ecology of Games Framework. Policy Stud. J. 2013, 41, 537-559. [CrossRef]

21. Berardo, R.; Lubell, M. Understanding what shapes a Polycentric Governance System. Public Adm. Rev. 2016, 76, 738-751. [CrossRef]

22. Consgrove, W.J.; Rijsberman, F.R. World Water Vision: Making Water Everybody's Business; Earthscan: London, UK, 2000.

23. Rogers, P.; Hall, A. Effective Water Governance; Global Water Partnership, TEC Background Papers. 2003. Available online: http://www.gwp.org/globalassets/global/gwp-cee_files/regional/governance-2003.pdf (accessed on 12 October 2016).

24. Tropp, H. Water governance: Trends and needs for new capacity development. Water Policy 2007, 9, 19-30. [CrossRef]

25. Allan, J.A. IWRM: The new sanctioned discourse? In IWRM in South Asia: Global Theory, Emerging Practice and Local Needs; Mollinga, P.P., Dixit, A., Athukorala, K., Eds.; Sage: New Delhi, India, 2006; pp. 38-63.

26. Pahl-Wostl, C. A conceptual framework for analyzing adaptive capacity and multi-level learning processes in resource governance regimes. Glob. Environ. Chang. 2009, 19, 345-365. [CrossRef]

27. Ostrom, V. A forgotten tradition: The constitutional level of analysis. In Polycentric Governance and Development: Readings from the Workshop in Political Theory and Policy Analysis; McGinnis, M.D., Ed.; University of Michigan Press: Ann Arbor, MI, USA, 1999.

28. Kostka, G.; Mol, A. Implementation and Participation in China's Local Environmental Politics: Challenges and Innovations. J. Environ. Policy Plan. 2013, 15, 3-16. [CrossRef]

29. Norman, E.S.; Bakker, K. Transgressing scales: Water governance across the Canada-U.S. borderland. Ann. Assoc. Am. Geogr. 2009, 99, 99-117. [CrossRef]

30. Hoff, H. Global water resources and their management. Curr. Opin. Environ. Sustain. 2009, 1, 141-147. [CrossRef]

31. Bots, P.W.G.; Bijlsma, R.; Korff, Y.V.; Van der Fluit, N.; Wolters, H. Supporting and constructive use of existing hydrological models in participatory settings: A set of "rules of the game". Ecol. Soc. 2011, 16, 16. [CrossRef]

32. Lubell, M.; Schneider, M.; Scholz, J.T.; Mete, M. Watershed Partnerships and the Emergence of Collective Action Institutions. Am. J. Political Sci. 2002, 46, 148-163. [CrossRef]

33. Han, H. China's policymaking in transition: A hydropower development case. J. Environ. Dev. 2013, 22, 313-336. [CrossRef]

34. Klijin, E.; Skelcher, C. Democracy and Network Governance: Compatible or Not? Public Adm. 2007, 85, 587-608. [CrossRef]

35. Scholz, J.T.; Berardo, R.; Kile, B. Do networks solve collective action problems? Credibility, search and collaboration. J. Politics 2008, 70, 393-406. [CrossRef] 
36. Marin, A.; Wellman, B. Social network analysis: An introduction. In Handbook of Social Network Analysis; Carrington, P., Scott, J., Eds.; Sage: London, UK, 2010.

37. O'Toole, L.J., Jr.; Kenneth, J.M. Networking in the penumbra: Public management, cooptative links, and distributional consequences. Int. Public Manag. J. 2006, 9, 271-294. [CrossRef]

38. Lubell, M.; Henery, A.D.; Mccoy, M. Collaborative institutions in an ecology of games. Am. J. Political Sci. 2010, 54, 287-300. [CrossRef]

39. Lubell, M.; Lippert, L. Integrated regional water management: A study of collaboration or water politics-as-usual in California, USA. Int. Rev. Adm. Sci. 2011, 77, 76-100. [CrossRef]

40. Scholz, J.T.; Wang, C.L. Cooptation or transformation? Local policy networks and federal regulatory enforcement. Am. J. Political Sci. 2006, 50, 81-97. [CrossRef]

41. Cashman, A.; Nurse, L.; John, C. Climate change in Caribbean: The water management implications. J. Environ. Dev. 2009, 19, 42-67. [CrossRef]

42. Li, W.; Liu, J.; Li, D. Getting their voices heard: Three cases of public participation in environmental protection in China. J. Environ. Manag. 2012, 98, 65-72. [CrossRef] [PubMed]

43. Sabatier, P.A.; Focht, W.; Lubell, M.; Trachtenberg, Z.; Vedlitz, A.; Matlock, M. Swimming Upstream: Collaborative Approaches to Watershed Management, American and Comparative Environmental Policy Series; The MIT Press: Cambridge, MA, USA, 2005.

44. Berardo, R. Bridging and Bonding Capital in Two-Mode Collaboration Networks. Policy Stud. J. 2014, 42, 197-225. [CrossRef]

45. Ratra, S. Comparing Water Governance in China \& India: Challenges \& Policy Options. Int. J. Water Resour. Dev. 2015, 31, 149-150. [CrossRef]

46. Katz, B. Reflections on Regionalism; Brookings Press: Washington, DC, USA, 2000.

47. Tang, X.; Liu, Z.; Yi, H. Mandatory targets and environmental performance: An analysis based on regression discontinuity design. Sustainability 2016, 8, 931. [CrossRef]

48. Ma, J.; Suo, L. The Multi-attribute of Water Resources and Network Governance Mode for Transboundary Water Conflict. Chin. Public Adm. 2010, 4, 81-84. (In Chinese)

49. Shenzhen, Dongguan and Huizhou formed a Half an Hour Commute. South Daily. Available online: http:/ /gd.people.com.cn/n2/2016/0223/c123932-27787721.html (accessed on 30 November 2017).

50. Xie, R. The Pilot City Implementation Scheme of Aquatic Ecologically Friendly City of Dongguan Has Passed the Evaluation. Available online: http://news.sun0769.com/dg/headnews/201401/t20140124_3389420_1. shtml (accessed on 13 July 2017).

51. Borgatti, S.P.; Everett, M.G.; Freeman, L.C. Ucinet for Windows: Software for Social Network Analysis; Analytic Technologies: Harvard, MA, USA, 2002.

52. Thompson, G. Between Hierarchies and Markets: The Logic and Limits of Network Forms of Organization; Oxford University Press: Oxford, UK, 2003.

53. Wellman, B.; Berkowitz, S.D. Structural Analysis in the Social Sciences 2: Social Structures: A Network Approach; Cambridge University Press: Cambridge, UK, 1988.

54. Otte, E.; Rousseau, R. Social network analysis: A powerful strategy, also for the information sciences. J. Inf. Sci. 2002, 28, 441. [CrossRef]

55. Granovetter, M. The strength of week ties. Am. J. Sociol. 1973, 78, 1360-1380. [CrossRef]

56. Peters, S.; Wals, A.E.J. Learning and knowing in pursuit of sustainability: Concepts and tools for trans-disciplinary environmental research. In Trading Zones in Environmental Education: Creating Transdisciplinary Dialogue; Krasny, M., Dillon, J., Eds.; Perter Lang: New York, NY, USA, 2013; pp. 79-104.

57. Dgwater.com. Key Responsibilities of Water Affairs Bureau. Available online: http://dgwater.dg.gov.cn/ dgWater/WebPage/IR_CommonPage_JGSZ.aspx?DH=ZYZN (accessed on 13 July 2017).

58. Scott, J. Social Network Analysis: A Handbook; Sage Publications: London, UK, 1991.

59. Chen, B.; Suo, L.; Ma, J. A network approach to interprovincial agreements: A study of Pan Pearl River Delta in China. State Local Gov. Rev. 2015, 47, 181-191. [CrossRef]

60. Ostrom, E. Governing the Commons: The Evolution of Instittions for Collective Action; Cambridge University Press: Cambridge, UK, 1990.

61. Cohen, M.D.; Riolo, R.L.; Axelrod, R. The role of social structure in the maintenance of cooperative regimes. Ration. Soc. 2001, 13, 5-32. [CrossRef] 
62. Ulibarri, N.; Scott, T. Linking Network Structure to Collaborative Governance. J. Public Adm. Res. Theory 2017, 1, 163-181. [CrossRef]

63. Granovetter, M. Economic Action and Social Structure: The Problem of Embeddedness. Am. J. Sociol. 1985, 91, 481-510. [CrossRef]

64. Putnam, R.D. Bowling Alone: The Collapse and Revival of American Community; Simon \& Schuster: New York, NY, USA, 2000.

65. Burts, R.S. The network structure of social capital. Res. Organ. Behav. 2000, 22, 345-423. [CrossRef]

66. Burts, R.S. Brokerage and Closure. An Introduction to Social Capital; Oxford University Press: Oxford, UK, 2005.

67. Wasserman, S.; Faust, K. Social Network Analysis: Methods and Applications; Cambridge University Press: New York, NY, USA, 1994.

68. Smythe, T.C.; Thompson, R.; Garcia-Quijano, C. The inner workings of collaboration in marine ecosystem-based management: A social network analysis approach. Mar. Policy 2014, 50, 117-125. [CrossRef]

69. Yi, H.; Scholz, J.T. Policy Networks in Complex Governance Subsystems: Observing and Comparing Hyperlink, Media, and Partnership Networks. Policy Stud. J. 2016, 44, 248-279. [CrossRef]

70. Jackson, M.O. Social and Economic Networks; Princeton University Press: Princeton, NJ, USA, 2008.

71. Freeman, L. Centrality in social networks. Soc. Netw. 1979, 1, 215-239. [CrossRef]

72. Provan, K.; Kenis, P. Modes of Network governance structure, Management and Effectiveness. J. Public Adm. Res. Theory 2008, 18, 229-252. [CrossRef]

73. Watts, D.J.; Strogatz, S.H. Collective Dynamics of "Small World" Networks. Nature 1998, 393, 440-442. [CrossRef] [PubMed]

74. Putnam, R.D. Bowling Alone: American's Declining Social Capital. J. Democr. 1995, 6, 65-78. [CrossRef]

75. Carpenter, D.P.; Esterling, K.M.; Lazer, D.M.J. Friends, Brokers, and Transitivity: Who informs who in Washington Politics? J. Politics 2004, 66, 224-246. [CrossRef]

76. Yeh, G.A.; Lee, T. Building a Competitive Pearl River Delta Region: Cooperation, Coordination, and Planning. In Proceedings of the Seminar on Building a Competitive Pearl River Delta Region: Cooperation, Coordination and Planning, Hong Kong, China, 8 July 2000.

77. Zhu, X.; Chen, S. Research on the Cooperation Mechanism between the government and NGOs in public crisis network governance in China. In Proceedings of the International Conference on Public Administration, Cape Town, South Africa, 31 October-2 November 2013.

78. Liu, Y.; Li, Y.; Xi, B.; Koppenjan, J. A governance network perspective on environmental conflicts in China: Findings from the Dalian paraxylene conflict. Policy Stud. 2016, 37, 314-331. [CrossRef]

79. Van Tuyen, T.; Armtage, D.; Marschke, M. Livelihoods and co-management in the Tam Giang lagoon, Vietnam. Ocean Coast. Manag. 2010, 53, 327-335. [CrossRef]

80. Bano, M. Negotiating collaboration in Pakistan: Expertise networks and community embeddedness. Public Adm. Dev. 2011, 31, 262-272. [CrossRef]

81. Palmer, C. Making a difference? Accounting for nongovernmental organizations in the comanagement of Lore Lindu national Park, Indonesia. J. Environ. Dev. 2014, 23, 417-445. [CrossRef]

(C) 2017 by the authors. Licensee MDPI, Basel, Switzerland. This article is an open access article distributed under the terms and conditions of the Creative Commons Attribution (CC BY) license (http:/ / creativecommons.org/licenses/by/4.0/). 